\title{
Analysis Students' Misconception in Optical Material Using Three Tier Multiple Choice Diagnostic Test
}

\author{
S. L. Handayani ${ }^{*}$ dan Arifin ${ }^{2}$ \\ ${ }^{1}$ Fakultas Keguruan dan Ilmu Pendidikan, Universitas Muhammadiyah Prof. DR. \\ HAMKA, Jakarta, Indonesia \\ ${ }^{2}$ Wardaya College, Jakarta, Indonesia \\ *Email: srilestarih@uhamka.ac.id
}

Received: May 16 th, 2021. Accepted: July 30th 2021. Published: August 29th, 2021

\begin{abstract}
This study aims to analyze the misconceptions of Senior High School students and their cause in Optical material. The data collection techniques used in this research are tests and interviews. The three tiers multiple-choice diagnostic test used consists of three levels, the first is a question, the second is the reason for the answer, and the third is the student's confidence level. The data analysis techniques used in this research are multiple-choice scoring analysis without fining and student's misconceptions level's percentage analysis. The lowest misconception level is $10.4 \%$ on the light refraction indicator, and the highest is $41.6 \%$ on the distance and characteristic of the image on the concave mirror. The sources of students' misconceptions found in this study are the students themselves, books, friends, teachers, students' daily experiences, and the Internet. (2021PERJ
\end{abstract}

Keywords: Diagnostic test; Misconception; Optic; Three-tier multiple choice. 


\section{INTRODUCTION}

A good teacher always tries to create effective learning. Every teacher tries to manage the students and possibly improve as much as possible by their capabilities. Not all of the students can achieve that improvement maximally in their learning processes. The student's failure the gaining academic prestige, which is not suited to the expected capacities, becomes a sign of the existence of the learning difficulties faced by the students (Suwarto, 2003). If students experience difficulties in the learning process will affect their ability to form concepts that are learned correctly and optimally. Misunderstanding by a student for a long time and students believe that the concept is true can make misconceptions. The students' misconceptions can become obstacles in constructing the whole concept at a higher level if the wrong concept becomes the foundation for new concepts at the higher level. Misconceptions can occur to anyone and any material, including materials in learning physics.

Wahyuningsih et al. (2013) found that students could not be separated from misconceptions in the physics study. Research of misconception needed to be developed to determine the success of the concept learning, which the teacher did. Observation, interviews, diagnostic tests, and documentation could investigate the students' learning difficulties.

The Physics study requires the students to be able to master the concept and principles of Physics correctly. Danar (2011) stated that the concept directly results from education and the foundation of thinking. The concept is the basis for a higher mental process to formulate the principles and generalization. The students must determine the necessary rules, and those rules are based on the concepts gained.

The true concept is a concept which a scientist finds. The concept of someone is called conception. The concept of a scientist is called scientist's conception, the concept of a teacher is teacher's conception, and the concept of a student is a student's conception. When the student's conception is not appropriate with the scientist's conception, it is called that the student has an alternative conception or misconception (Suparno, 2013).

Kose (2008) stated that misconception is built by the students uncertainly and different from accepted scientific concept, so it is needed a misconception determination which the students experience. Misconception becomes a source of the doubt when it is inappropriate with a new concept and disturbs the learning process. The misconception cause can be from the students, teachers, textbooks, context, and teaching 
methods (Wahyuningsih et al., 2013; Suparno, 2013).

Tekkaya (2002) found that teachers can play the role of students' misconceptions experienced. Teachers who have not mastered the material or do not understand Physics correctly will cause misconceptions. Teachers shouldn't only assess and listen to the student complaint to get information about students' understanding. A very complicated textbook for student-level learning Physics, diagrams, and an appropriate image can cause the students' misconceptions (Suparno, 2013; Gurel dan Ali, 2013).

This study uses a three-tier multiple-choice diagnostic test to uncover student's misconceptions. A diagnostic test is a useful tool to verify students' knowledge and ensure students' misconceptions with proper repair techniques in the selected subjects' active learning (Vichitvejpaisal et al., 2011).

Three-tier multiple-choice diagnostic tests consist of three levels. The first level is the level of questions that consists of questions that four answer options are determined. The second level is the level of reason consists of four choices reasons (three reasons specified and one reason open), and the third level is the level of confidence of students consisting of six options confidences.

\section{METHODS}

This study aims to uncover misconceptions of Senior High School students on Optical materials using valid and reliable three multiple-choice diagnostic tests that are previously developed and reveal the causes of students' misconceptions. The data used in this study is the documentation, test, and interview. The test was given to 125 students of the $10^{\text {th }}$ class in one of the state high schools in Central Java. The sample consisted of 41 male students and 85 female students. Interviews were conducted on 24 students to represent the findings of misconceptions.

Data analysis techniques include analyzing test interpretation, analyzing the level of student misconceptions using percentages, and scoring tests using multiple choice scoring formula without penalty. Diagnostic tests used in the selection of this research have been developed previously. In early development, the number of multiple-choice questions of diagnostic test three levels in this study was 67 questions representing the 21 questions indicators. Then, it was subtracted until 22 questions after testing small-scale and largescale trials. The final total of the three-tier multiple-choice questions used to reveal students' misconceptions on optical material is 45 questions representing the 12 questions indicators. 


\section{RESULT AND DISCUSSION}

After field testing, data analysis results, misconceptions grouping percentage of students can be seen in Figure 1. Based on Figure 1, the misconception was lowest of $10.4 \%$ at a low level of refraction and related quantities. Low levels of misconceptions in the refraction process provide information that not many students have misconceptions about the refraction of light materials. The highest misconception of $41.6 \%$ was classified as moderate in determining the center of curvature, the distance of image, and the image on the nature of the concave mirror. The misconception in the highest indicator provides information found in most students who have misconceptions on these indicators. It takes a lot more attention from teachers to teach the material that includes five indicators.

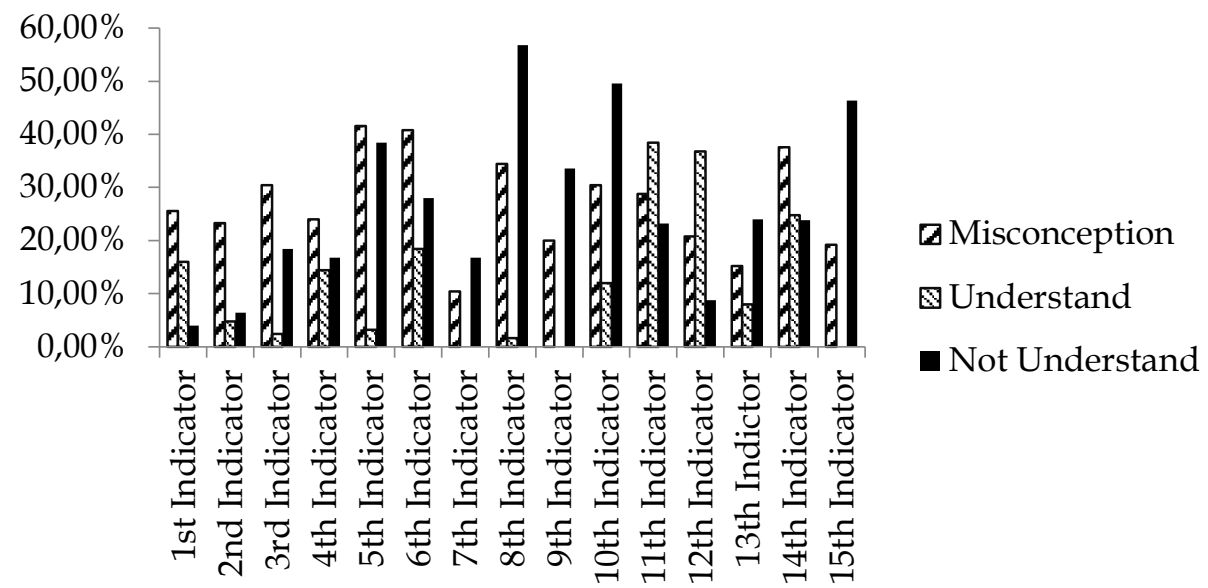

Figure 1. Clustering Analysis Student Misconceptions

Based on Figure 1, nine indicators experienced relatively low levels of misconceptions, and six were classified as moderate. The presence of six indicators is categorized as providing information that most students have misconceptions about the indicator.

Figure 2 shows the number of grouping students into three categories: misconceptions, understand, and do not understand. Based on Figure 2, it can be seen that students are categorized as high misconceptions as much as $7.2 \%$ (nine students), students' misconceptions were categorized as $30.45 \%$ (38 students) and common student misconceptions categorized as $62.4 \%$ (78 students). These results provide information that misconception on optical materials studied is dominant to the misconceptions categorized as lowlevel. Most of the students have misconceptions about certain parts of the optical material. A total of 38 of the 125 students had 
misconceptions with moderate levels, providing as much information as 38 students had misconceptions on just over half of the optical material. A total of nine students were included in the category of misconceptions with a high level informs that nine students are experiencing misconceptions of almost all optical materials.

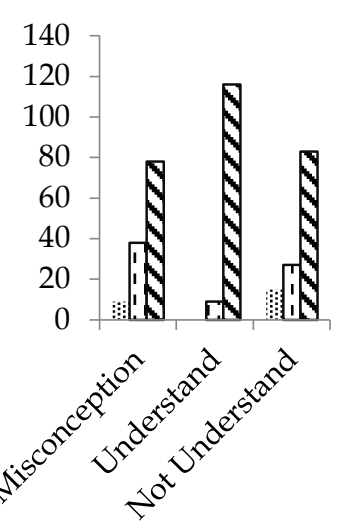

Figure 2. Grouping Students Misconceptions, Understand and Do not Understand

Data showed that as much as $0 \%$ (no student) belonging to the highlevel understanding, as much as $7.2 \%$ (nine students) were classified as moderate understanding. As much as $92.8 \%$ (116 students) were classified as understanding with low levels. These results provide information that none of the students who mastered all the concepts properly Optical materials, only nine of the 125 students who ruled much of the concept of optical materials, and almost all students (116 of 125 students) did not control nearly all optical materials.
For the category of not understanding, data showed that $12 \%$ of students ( 15 of 125 students) included categories did not understand the high level, which means that as many as 15 students did not understand most of the concepts in optical materials. A total of $21.6 \%$ of students ( 27 of 125 students) are included in the category are not familiar with the medium level, which means that 27 students did not understand most of the concepts of optical materials. A total of $66.4 \%$ of students ( 83 of 125 students) including in the category are not familiar with low level, which means that as many as 83 students did not understand fraction concepts Optics material.

The concept is built after a student learning becomes important to know whether the students' conceptions follow a scientist's conception. Dahar (2011) stated that the concept results from education and concepts as the building blocks of thought. The concept of the students is a basis for developing the right frame.

Based on the students' misconception analysis result it acquires the six types of misconceptions, which are the same with Suniati et al. (2013) 's research, they are the characteristics of an image on a flat mirror, the reflection properties of a convex mirror, refraction in the lens, describing the process of forming an image on the lens, the process of seeing things, the characteristics of image and image 
on the loop magnification. Two common forms of misconceptions are the same with Tekkos and Christina (2009) research. There are namely the light reflection and diffusion of light, and the students have trouble distinguishing between the angle of incidence to the angle of reflection. The results also suggest that two forms of misconceptions are similar to Aydin's (2012) research that covers misconceptions on the reflectance of light. The light passes through a concave mirror and a convex mirror. The light will be refracted into the back of the mirror.

The misconceptions findings in this study have the same shape misconceptions as Ouattara and Barthelemie's (2012) and Djanette et al. (2009) research. One similarity of the misconception shape with Ouattara and Barthelemie's (2012) research is that the students have difficulties distinguishing between natural light and a virtual light on the lens. There are two similarities of the misconception with Djanette et al. (2009) research: the formation of an image on reflection and the center of the lens is responsible for the formation of images.

There are 13 forms another common misconception that is grouped based on the misconceptions findings in this study. The other general form of the misconceptions that are found includes the characteristic of light propagates straight, light reflection on a flat mirror, cannot distinguish between the real and virtual image on the mirror, cannot distinguish between divergent and convergent beam at the mirror, forming an image on the concave mirror, concave mirror-image properties, division of space objects and space image, focus distance, the distance an image on the concave mirror, can not distinguish between a concave mirror and a convex mirror, convex mirror image formation, nature and magnification image on the convex lens, the eye can not distinguish between defects and hypermetropic and myopia, the process of forming an image on the microscope, and the characteristics of the image on the binoculars.

Based on the interviews of students to explore the students' misconceptions obtained several sources that cause those student's misconceptions, they are:

Student

Wahyuningsih et al. (2013) and Suparno (2013) mention that the students are a source of misconceptions. For example, students think that starting to see an object is starting from a light source into the eyes, then reflect the object; the object has reflected the eye so that their eyes can see objects.

Books

Based on the interviews, textbooks and notebooks belong to one source of students' misconceptions. Gurel and Ali (2013) and Suparno (2013) state that the textbooks are too difficult for students who are learning Physics; 
diagrams and images that are less precise can lead to students' misconceptions. As an example of a book as a source of misconceptions found in the concept of diffuse reflection. Students stated that the diffuse law reflectance does not apply in the reflection process. Students say that the magnitude of the angle of incidence and reflection angle on the diffuse reflectance is not the same as the book described that diffuse reflectance is the reflectance of light everywhere, so it does not apply the law of reflection. Friends

Another source of misconceptions is friends. For example, assume that a student defect myopia occurs because the eye's lens cannot be thickened, and hypermetropic occurs because the eye's lens cannot be flattened and requires negative lens glasses.

\section{Teachers}

Tekkaya (2002), in his research, found that teachers can play the role of misconceptions experienced by students. Teachers who have not mastered the material or do not understand the physics correctly will cause the students to have misconceptions. It is found in this study. The students stated that the convex mirror has an image of the same nature as the concave mirror, and the student obtains such information from the tutor.

Life Experiences

Everyday experience can lead to student misconceptions. For example, the study found that students assume that a convex mirror produces a magnified image due to scattering light. This assumption is based on the student's experience when the student sees himself in the rear-view mirror of the motor. When students are in the rear-view mirror, they see an image over his face and think his face in the rear-view enlarged because all of the student's faces are looked at, which causes them to think that convex mirrors produce magnified image properties.

The Internet

The source of misconceptions can come from the Internet. For instance, the student states that the positive lens is used in the loop is to spread the light. Students inform that he gained this information after searching on the Internet regarding the material and found that the lens optics are spreading positive light and considers that concept is true.

\section{CONCLUSION}

Based on the result and discussion, it shows that the lowest misconceptions level is $10.4 \%$ on the indicator to understand the process of the refraction of light and the amount involved, and the highest misconception level is $41.6 \%$ on the indicator to determine the distance of an image and reflection properties of the concave mirror. The sources of misconceptions experienced by students in this study are the students themselves, books, friends, teachers, everyday experiences, and 
the Internet. These results can make a reference and basis for improving the learning process for physics, especially optical materials. Students need help to improve their misconceptions through learning that emphasizes learning, making it easier for them to form concepts correctly. The teacher's role is very important in helping students overcome their misconceptions.

\section{REFERENCES}

Aydin, S. (2012). Remediation of Misconceptions about Geometric Optics Using Conceptual Change Texts. Journal of Education Research and Behavioral Sciences, 1 (1), 1-12.

Dahar, R. W. (2011). Theories of Teaching and Learning. Jakarta: Publisher

Djanette, B., Chafiqi, F., and Kendil, D. (2009). Students Misconceptions about Light in Algeria. Education and Training in Optics and Photonics. Conference Paper. St. Asaph, North Wales United Kingdom, June 5 to 7.

Gurel, D.K and Ali, E. (2013). A Content Analysis of Physics Textbooks as a Probable Source of Misconceptions in Geometric Optics. Hacettepe University Journal of Education, 28 (2), 234-245.

Kose, S. (2008). Diagnosing Student Misconceptions: Using Drawings as a Research
Method. World Applied Sciences Journal, 3 (2), 283293.

Ouattara, F. and Barthelemie, B. (2012). Teaching and Learning in Geometrical Optics in Burkina Faso Third Form Classes: Presentation and Analysis of Data and Observations Class Students' Performance. British Journal of Science, 5 (1), 83-103.

Suniati, NMS, Wayan, S., and Anggan, S. (2013). Effects of Contextual Learning Implementation Cosmos Interactive Multimedia Assisted misconception Decrease (QuasiExperimental Study in Learning Light and Optics in SMP Negeri 2 Amlapura). EJournal University Graduate School of Education Ganesha, 4. Suparno, P. (2013). Miskonsepsi dan Perubahan Konsep dalam Pendidikan Fisika. Jakarta: PT Grasindo.

Suwarto. (2013). Pengembangan Tes Diagnostik Dalam Pembelajaran (Panduan Praktis Bagi Pendidik dan Calon Pendidik. Yogyakarta: Pustaka Pelajar.

Tekkaya, C. (2002). Misconceptions as Barrier to Understanding Biology. Hacettepe Universitesi Dergisi Egitim Fakultesi, 23, 259-266.

Tekos, G. and Christina, S. (2009). Constructivist Learning and Teaching of Optics Concepts 
Using ICT Tools in Greek Primary School: A Pilot Study. J Sci Educ Technol, 18, 415-428.

Vichitvejpaisal, P., Vorakran, J., Tippawan, P., Pinda, V., Parichad A., Suthisa, C., Kanitha, K., Phetcharee, C. (2011). Developing a TwoTier Diagnostic Test to Assess Arterial Blood Gases Learning by Students with
Different Background Knowledge in Anesthesiology. South East Asian Journal of Medical Education, 5 (2), 27-33.

Wahyuningsih, T., Trustho, R., and Dyah, FM (2013). Diagnostic Test Instrument Making High School Physics Class XI. Journal of Physical Education, 1 (1), 111-117. 
Phy. Educ. Res. J. Vol. 3 No. 2 (2021), 75-84 